\title{
Analysis of Time Delay and Cost Overrun in Road Construction
}

\author{
Anish C., Kiruthiga K., Vinoth S.
}

\begin{abstract}
Road construction is the important division in the construction industry and the most predominant part of a society. The roadway defines the development of a country or a state and brings in the economic development of the same. The reasons for choosing a project on the roadways are its vast scope of day to day development and progress in this area.

Thus it is clearly seen that roadways is the most essential in todays world without which progress and development cannot take place at full fledge. Therefore any delay in completion of a road constructing project may have its impact in degrading of a society. Also at the same time the budget overrun or cost overrun of such project is highly unbearable.
\end{abstract}

Key Word: Roadway, Cost Over Run

\section{INTRODUCTION}

Deferral as alluded in development is delayed development period and interruptions of occasions that exasperate the development program. Deferrals and Cost overwhelm are among the difficulties looked throughout executing development ventures. Postponements just as cost invade are wellsprings of potential dangers that present examinations are investigating approaches to oversee. Development postponement is characterized as "the time overwhelm either past fulfillment date indicated in an agreement, or past the date that the gatherings settled upon for conveyance of a venture." Delay is likewise characterized as a "demonstration or occasion which stretches out expected time to perform or finish work of the agreement shows itself as extra long stretches of work"

\section{.II. METHODOLOGY}

The Data are collected through two methods namely questionnaire and case study. Questionnaires are conducted from few concerned persons. This survey helps in finding the Relative

Importance Index (RII), later this value is used in determining cost variation that occurs in project that are concerned under case study.

Likewise, for the finding out time delay process, time schedules and activity schedules are collected from the case study of specified projects.

Finally, factors leading for both cost overrun and time delay are displayed in charts, so that the intensity of the factors and its performance to hinder the actual cost budget and time schedule of the project are clearly studied.

\section{RESULTS AND DATA ANALYSIS}

\section{A. Data Collection}

Simple questionnaire survey were conducted to individuals concerned in the highway projects. The result of the survey was the input to determine the Relative Importance Index (RII). Relative Importance Index (RII) calculation is used to determine relative significance and ranking of cost and overrun factors.

\section{B. Data Analysis}

The The data received through the survey had 16 respondents and they are categorised in the fig .1

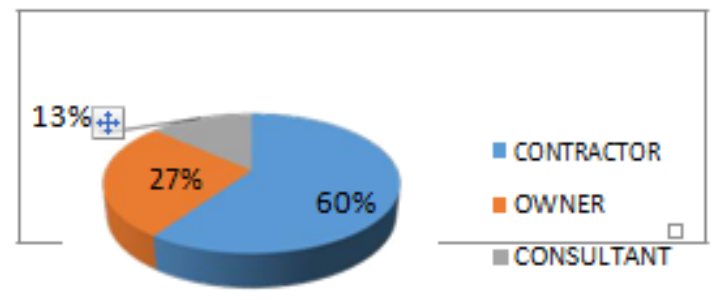

Figure.1.Data Analysis 


\section{Cost Overrun And Time Delay Factors (Expressed In Charts)}

The Various surveys are conducted as mentioned and the results are expressed using charts for convenient purpose. These charts shows the ranking positions of each factor which is numbered then using the mean value obtained from the survey conducted. The result of the survey are processed and analysed in the SPSS software tool.

\section{Factors Related To Financial Groups}

In this chart, factors are ranked from very high influencing factors to very low influence factors as shown in figure 6.2 and they are denoted by,

\section{Ca1 -Market demand}

$\mathrm{Ca} 2$ - Increase in tax

Ca3 - Poor financial control in site

Ca4 - Delay in payment to supplier/sub-contractor

Ca5 - Bureaucracy in tendering method

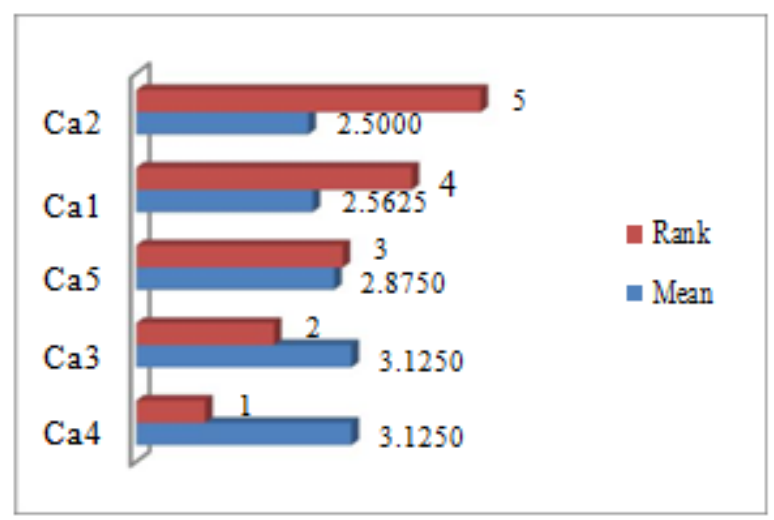

Figure.2. Factors related to financial groups

\section{E. Factors Related To Construction Parties}

In this chart, factors are ranked from very high influencing factors to very low influence factors as shown in Figure 5.5 and they are denoted by,

Cb1 - Lack of information flow between parties

$\mathrm{Cb} 2$ - Lack of co-ordination between projects

Cb3 - Lack of communication between parties

Cb4 - Lack of qualified project manager

Cb5 -Lack of experience in line of work

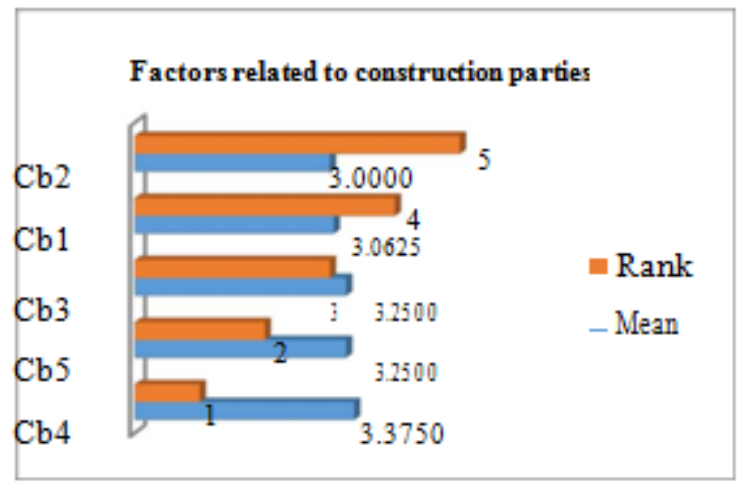

Figure.3. Factors related to construction parties

\section{F. Factors Related To Construction Items}

Use In this chart, factors are ranked from very high influencing factors to very low influence factors as shown in figure 5.6 and they are denoted by,

Cc1 - Incomplete design and drawing

Cc2 - Slow inspection of completed work

Cc3 - Wastage of materials in the site

Cc4 - Inadequate review of contract documents and specifications

Cc5 - Inadequate quantity takeoff

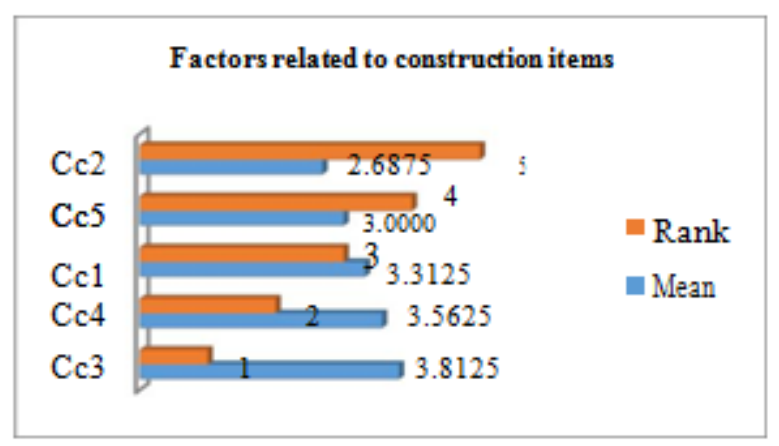

Then the sample was fused with $0.1 \quad \mathrm{~N}$ of $\mathrm{NaOH}$ with the removal of iron and tested for CEC which yielded a value of $20 \mathrm{meq} / \mathrm{L}$.

Then the sample was fused with sodium aluminate without the addition of $\mathrm{NaOH}$ and tested for $\mathrm{CEC}$ which yielded a value of $20 \mathrm{meq} / \mathrm{L}$.

From the above tests the effect of removal of iron and addition of $\mathrm{NaOH}$ was understood. Moreover when the sample was dried and then ground a paste like substance was formed which was dried and then the various parameters like temperature and time were tried out. There are a lot of other possibilities which can be tried out by varying the Molarity of 
$\mathrm{NaoH}$ and the concentration of Sodium Aluminate

\begin{tabular}{|l|l|l|}
\hline $\begin{array}{l}\text { Sl } \\
\text { no }\end{array}$ & Description & Value in \% \\
\hline 1 & $\mathrm{SiO}_{2}$ & 51.17 \\
\hline 2 & $\mathrm{Al}_{2} \mathrm{O}_{3}$ & 38.7 \\
\hline 3 & $\mathrm{Fe}_{2} \mathrm{O}_{3}$ & 8.99 \\
\hline 4 & $\mathrm{CaQ}$ & 0.14 \\
\hline 5 & $\mathrm{MgQ}$ & 0.14 \\
\hline
\end{tabular}

Figure.4. Factors related to construction items

\section{G. Factors Related To Environmental Group}

In this chart, factors are ranked from very high influencing factors to very low influence factors as shown in figure 5.7 and they are denoted by,

\section{Cd1 - Weather condition \\ $\mathrm{Cd} 2$ - Geological condition of project site \\ $\mathrm{Cd} 3$ - Social and cultural impacts \\ $\mathrm{Cd} 4$ - Law and regulations \\ Cd5 - Location of project}

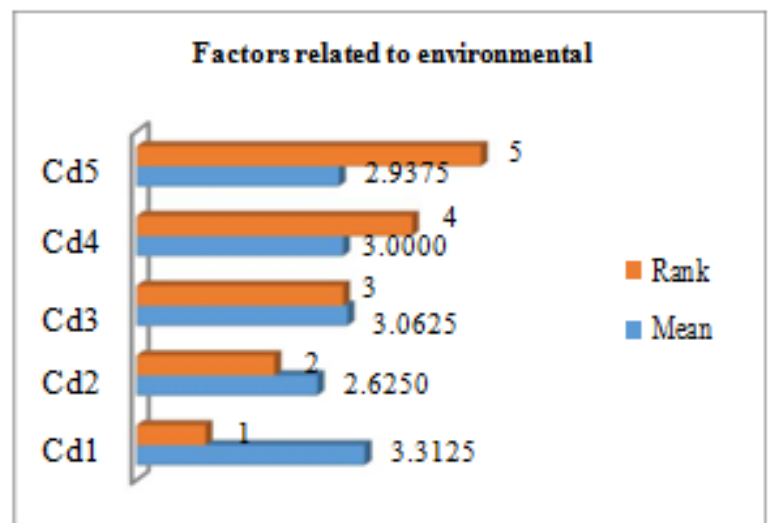

Figure.5. Factors related to environmental

\section{H. Factors Related To External Group}

In this chart, factors are ranked from very high influencing factors to very low influence factors as shown in figure 5.8 and they are denoted by,

Ce1 - Exclusive control of certain group of material suppliers $\mathrm{Ce} 2$ - Difficulty in importing materials and equipments

Ce3 - Political situation

$\mathrm{Ce} 4$ - Dealing with suppliers and traders

Ce5 - Permits or Approvals for land procurement and acquisition

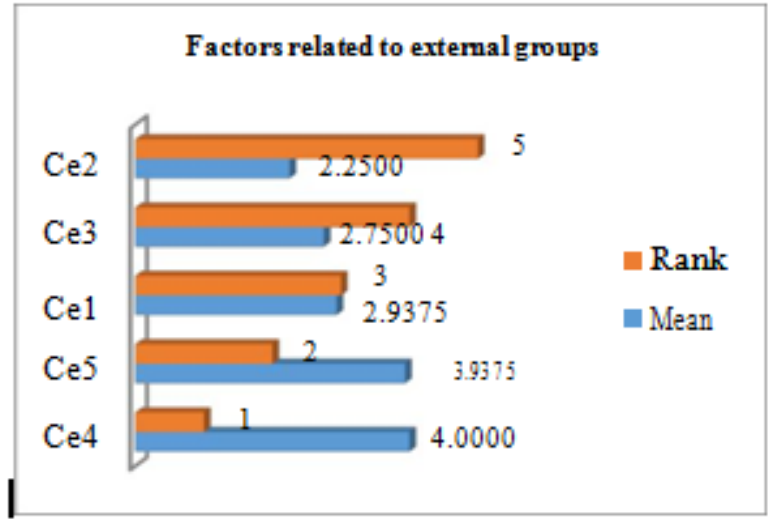

Figure.6. Factors related to external group

\section{Factors Related To Materials}

In this chart, factors are ranked from very high influencing factors to very low influence factors as shown in figure 5.9 and they are denoted by,

Cf1 - Shortage of material

Cf2 - Late delivery of materials

Cf3 - Escalation of material price

Cf4 - Change in material specification

Cf5 - Wastage of materials

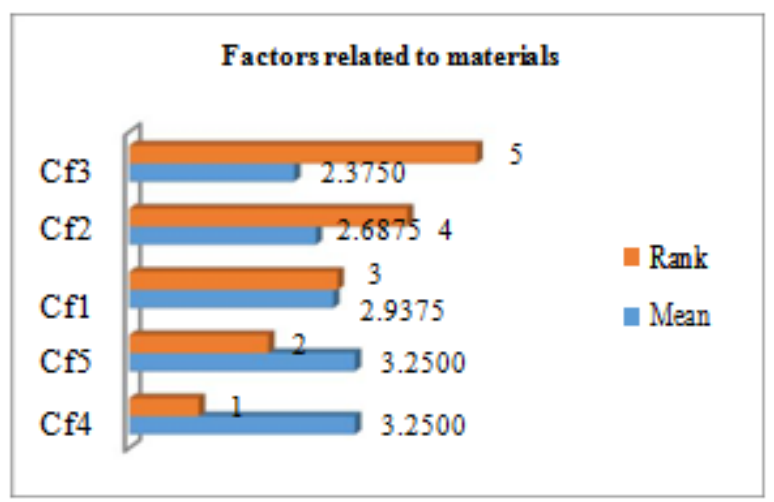

Figure.7. Factors related to materials

\section{J. Factors Related To Labor And Equipment}

In this chart, factors are ranked from very high influencing factors to very low influence factors as shown in figure 5.10 and they are denoted by,

$\mathrm{Cg} 1$ - Lack of availability of equipment

$\mathrm{Cg} 2$ - Inadequate labour productivity

$\mathrm{Cg} 3$-High cost of machinery and labour

Cg4 -Frequent breakdown of construction plant and equipment

Cg5 -High transportation cost 


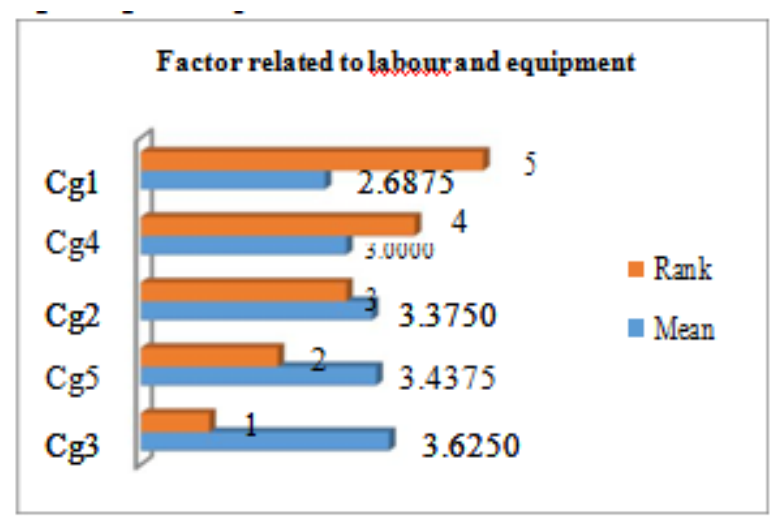

Figure.8. Factors related to labor and equipment

\section{K. Factors Related To Owners}

In this chart, factors are ranked from very high influencing factors to very low influence factors as shown in figure 5.11 and they are denoted by,

Ch1 - Additional work at owner's request

Ch2 - Owner's unwillingness to help

Ch3 - Delay in progress payment by owner

Ch4 - Owner's emphasis on high quality

Ch5 - Delay in decision making

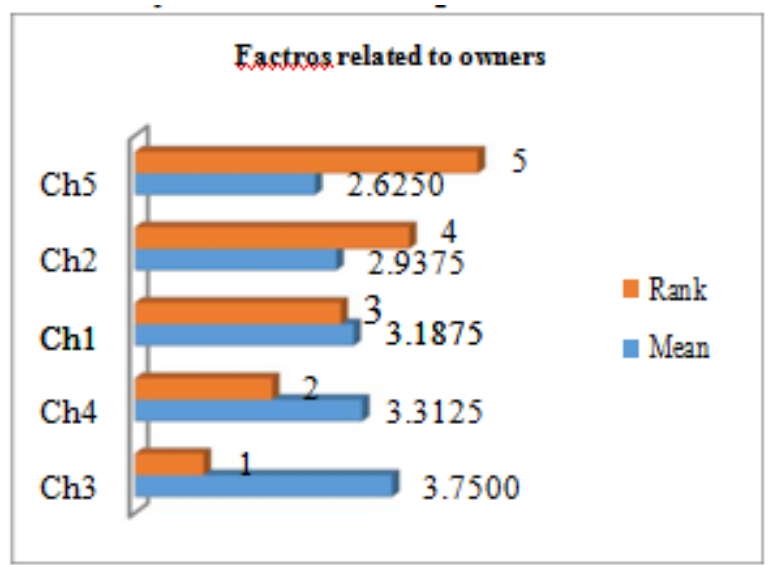

Figure.9.Factors related to owners

\section{Factors Related to Project Delays}

In this chart, factors are ranked from very high influencing factors to very low influence factors as shown in figure 5.12 and they are denoted by,

Ta1 - Inconvenient site access

Ta2 - Disturbance to public activities

Ta3 - Limited construction area

Ta4 - Poor terrain condition

Ta5 - Poor soil drillability and laying suitability

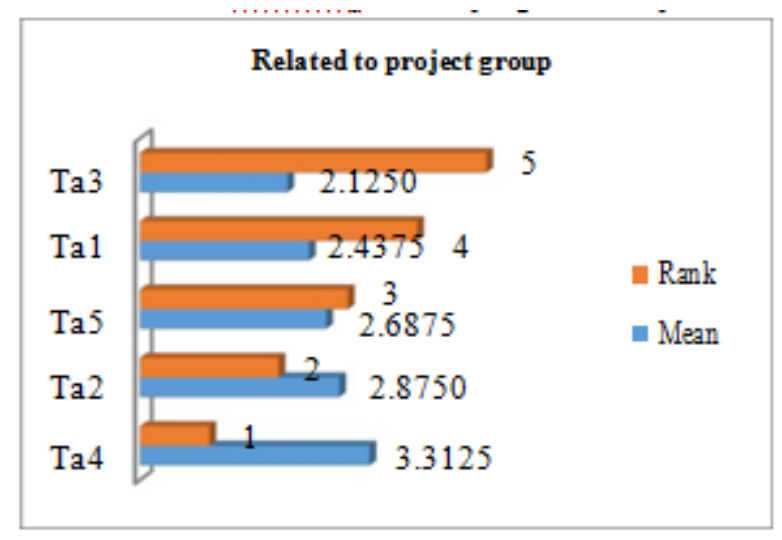

Figure.10.Factors related to Projrect Group

\section{Factors Related To Internal Delay Factors}

In this chart, factors are ranked from very high influencing factors to very low influence factors as shown in figure 5.13 and they are denoted by,

Tb1 - Change orders by the owner during construction $\mathrm{Tb} 2$ - Delay in progressing payments

Tb3 - Ineffective planning and scheduling by the contractor Tb4 - Poor site management by the contractor

Tb5 - Shortage of labours

Tb6 - Difficulties in financing the project by the contractor

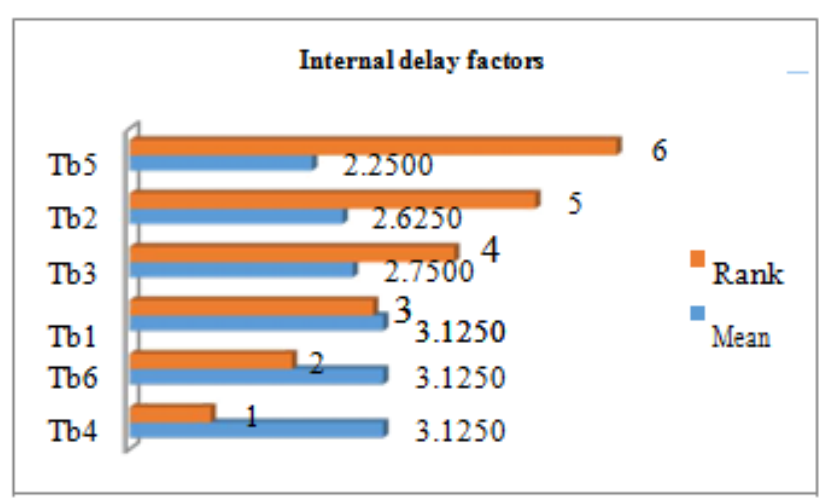

Figure.11.Internal delay factors

\section{N. Factors Related To Managerial Group}

In this chart, factors are ranked from very high influencing factors to very low influence factors as shown in figure 5.14 and they are denoted by,

Tc1 - Poor communication between construction parties Tc2 - Delays in decision making Tc3 - Unreasonable project time frame Tc4 - Improper construction method Tc5 - Late issuing of approval documents and late land hand over 


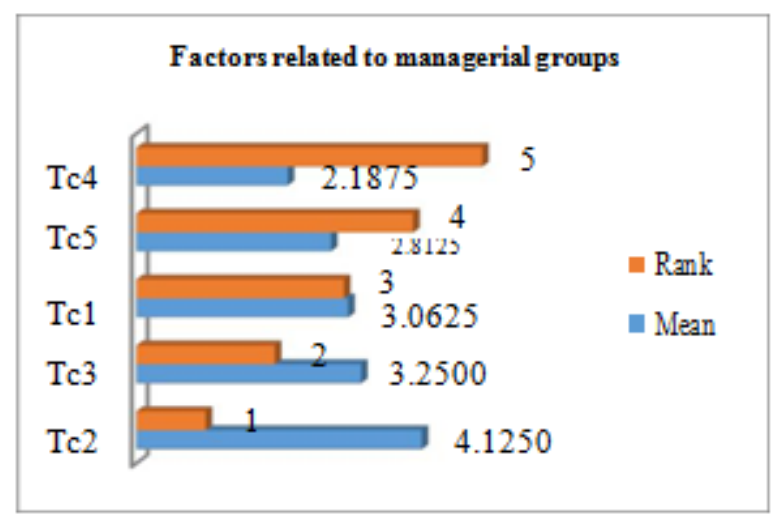

Figure.12. Factors related to managerial groups

\section{O. Factors Related To Consultant Group}

In this chart, factors are ranked from very high influencing factors to very low influence factors as shown in figure 5.15 and they are denoted by,

Td1 - Mistakes in design

Td2 - Design changes \& inappropriate design

Td3 - Late inspection and late approval

Td4 - Insufficient and incapable inspectors

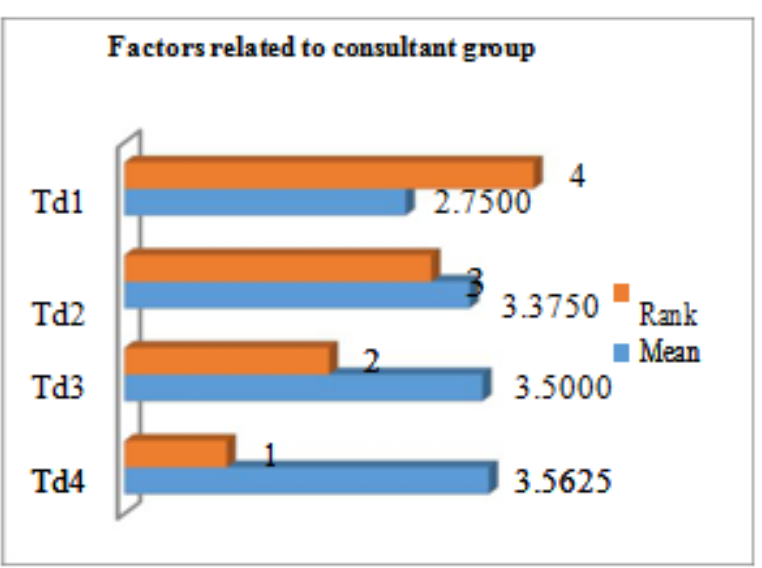

Figure.13. Factors related to consultant group

\section{K. Factors Related To Financial Group}

In this chart, factors are ranked from very high influencing factors to very low influence factors as shown in figure 5.16 and they are denoted by,

Te1 - Payments delay by the owner

Te2 - Financial status of contractor

Te3 - Financial status of contractor

Te4 - Exchange rate fluctuation

Te5 - Inflation

Te6 - Monopoly

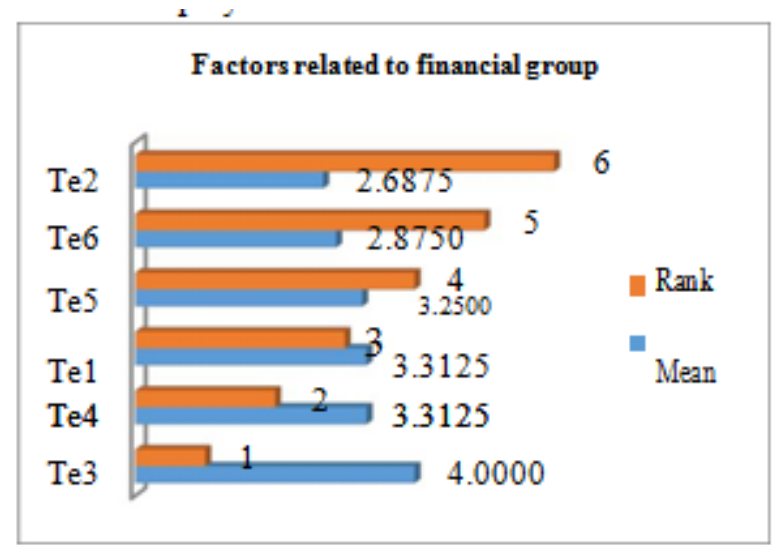

Figure.14. Factors related to financial group

\section{Factors Related To External Group}

In this chart, factors are ranked from very high influencing factors to very low influence factors as shown in figure 5.17 and they are denoted by,

Tf2 - Segmentation of West bank

Tf3 - Weather condition

Tf4 - Natural disaster

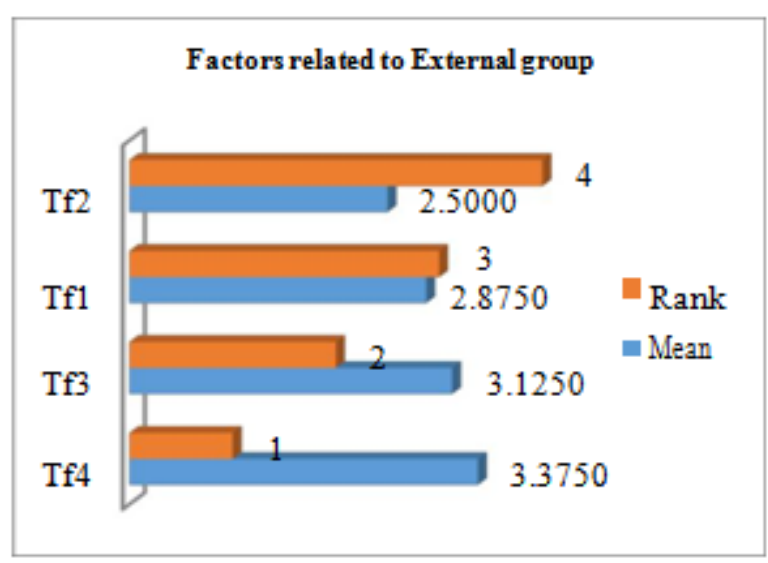

Figure.15. Factors related to external group

\section{K. Factors Related To Construction Item Group}

In this chart, factors are ranked from very high influencing factors to very low influence factors as shown in figure 5.18 and they are denoted by,

Tg1 - Insufficient labours

Tg2 - Rework from poor workmanship

Tg3 - Lack of Equipment efficiency

$\mathrm{Tg} 4$ - Unavailable construction material

Tg5 - Rework from poor material quality 


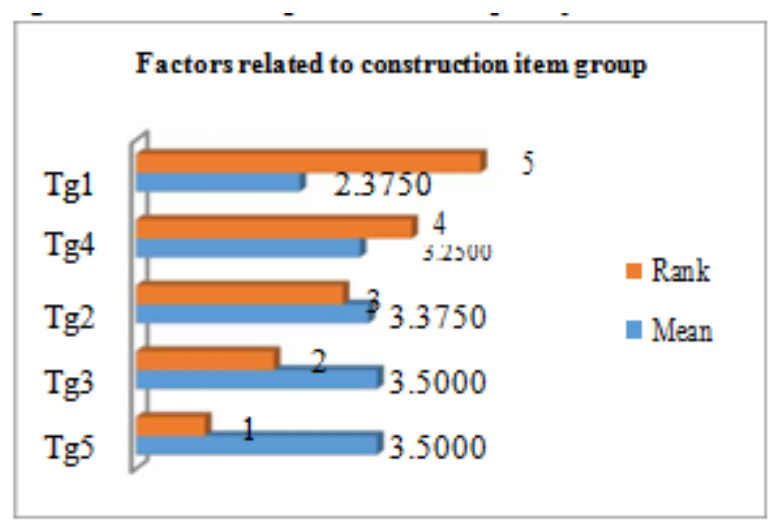

Figure.16. Factors related to construction items Group

\section{CONCLUSION}

Road construction is the important division in the construction industry and the most predominant part of a society. The delay in completion of a road constructing project may have its impact in degrading of a society. Delays are insidious often resulting in time overrun, cost overrun, disputes, litigation, and complete abandonment of projects. The factors analyzed in this project are evitable practically if the correct source starts repairing the root cause. The rectification cost overrun and time delay can bedone only by the cooperation of all the groups associated with theconstruction industry. This project does not mean if things are done as per stated in this paper would rectify all the problems and difficulties faced in the industry, but a considerable amount ofchanges can be brought which may save a lot of amount and time.

\section{REFERENCES}

1. Iyappan L., Dayakar P., Identification of landslide prone zone for coonoortalukusing spatial technology, International Journal of Applied Engineering Research,V-9,I-22,PP-5724-5732,Y-2014.

2. Kumar J., Sathish Kumar K., Dayakar P.,Effect of microsilica on high strength concrete, International Journal of Applied Engineering Research,V-9,I-22,PP-5427-5432,Y-2014.

3. Dayakar P., Vijay Ruthrapathi G., Prakesh J., Management of bio-medical waste, International Journal of Applied Engineering Research,V-9,I-22,PP-5518-5526,Y-2014.

4. Swaminathan N., Dayakar P., Resource optimization in construction project, International Journal of Applied Engineering Research,V-9,I-22,PP-5546-5551,Y-2014.

5. Venkat Raman K., Dayakar P., Raju K.V.B.,An experimental study on effect of cone diameters in penetration test on sandy soil, International Journal of Civil Engineering and Technology,V-8,I-8,PP-1581-1588,Y-2017.

6. Saritha B., Chockalingam M.P.,Photodradation of malachite green DYE using TIO2/activated carbon composite,International Journal of Civil Engineering and Technology,V-8,I-8,PP-156-163,Y-2017

7. Shendge R.B., Chockalingam M.P., Saritha B., Ambica A.,Swat modelling for sediment yield: A case study of Ujjani reservoir in Maharashtra, India,International Journal of Civil Engineering and Technology,V-9,I-1,PP-245-252,Y-2018

8. Chockalingam M.P., Balamurgan V.,Modernisation of an existing urban road-sector in Chennai, a case study report,International Journal of Civil Engineering and Technology,V-8,I-8,PP-1457-1467,Y-2017

9. Saritha B., Chockalingam M.P.,Adsorption study on removal of basic dye by modified coconut shell adsorbent, International Journal of Civil Engineering and Technology,V-8,I-8,PP-1370-1374,Y-2017

10. Saritha B., Chockalingam M.P.,Adsorptive removal of heavy metal chromium from aqueous medium using modified natural adsorbent,International Journal of Civil Engineering and Technology,V-8,I-8,PP-1382-1387,Y-2017

11. Chockalingam M.P., Palanivelraja S.,Retrospective analysis of a theoretical model used for forecasting future air quality near the north Chennai thermal power plant,International Journal of Civil Engineering and Technology,V-8,I-8,PP-1457-1467,Y-2017

12. Saritha B., Chockalingam M.P.,Photodegradation of methylene blue dye in aqueous medium by $\mathrm{Fe}-\mathrm{AC} / \mathrm{TiO} 2$ Composite,Nature Environment and Pollution Technology,V-17,I-4,PP-1259-1265,Y-2018

13. Shendge R.B., Chockalingam M.P., Kaviya B., Ambica A.,Estimates of potential evapotranspiration rates by three methods in upper Bhima Basin, In Maharashtra, India,International Journal of Civil Engineering and Technology,V-9,I-2,PP-475-480,Y-2018

14. Shendge R.B., Chockalingam M.P.,The soil and water assessment tool for Ujjani Reservoir,International Journal of Mechanical Engineering and Technology,V-9,I-2,PP-354-359,Y-2018

15. Shendge R.B., Chockalingam M.P.,A review on soil and water assessment tool,International Journal of Mechanical Engineering and Technology,V-9,I-2,PP-347-353,Y-2018

16. Sachithanandam P., Meikandaan T.P., Srividya T.,Steel framed multi storey residential building analysis and design,International Journal of Applied Engineering Research,V-9,I-22,PP-5527-5529,Y-2014

17. Meikandaan T.P., Ramachandra Murthy A.,Study of damaged RC beams repaired by bonding of CFRP laminates, International Journal of Civil Engineering and Technology,V-8,I-2,PP-470-486,Y-2017

18. Meikandaan T.P., Ramachandra Murthy A.,Retrofittng of reinforced concrete beams using GFRP overlays,International Journal of Civil Engineering and Technology,V-8,I-2,PP-423-439,Y-2017

19. Meikandaan T.P., Ramachandra Murthy A.,Flexural behaviour of RC beam wrapped with GFRP sheets,International Journal of Civil Engineering and Technology,V-8,I-2,PP-452-469,Y-2017

20. Meikandaan T.P., Murthy A.R.,Experimental study on strengthening of rc beams using glass Fiber,International Journal of Civil Engineering and Technology,V-9,I-11,PP-959-965,Y-2018

21. Meikandaan T.P., Hemapriya M.,Use of glass FRP sheets as external flexural reinforcement in RCC Beam,International Journal of Civil Engineering and Technology,V-8,I-8,PP-1485-1501,Y-2017

22. Saraswathy R., Saritha B.,Planning of integrated satellite township at Thirumazhisai,International Journal of Applied Engineering Research,V-9,I-22,PP-5558-5560,Y-2014

23. Saritha B., Ilayaraja K., Eqyaabal Z.,Geo textiles and geo synthetics for soil reinforcement,International Journal of Applied Engineering Research,V-9,I-22,PP-5533-5536,Y-2014

24. Ambica A., Saritha B., Changring G., Singh N B., Rajen M., Salman Md.,Analysis of groundwater quality in and around Tambaram taluk, Kancheepuram district,International Journal of Civil Engineering and Technology,V-8,I-8,PP-1362-1369,Y-2017

25. Arunya A., Sarayu K., Ramachandra Murthy A., Iyer N.R.,Enhancement of durability properties of bioconcrete incorporated with nano silica,International Journal of Civil Engineering and Technology,V-8,I-8,PP-1388-1394,Y-2017

26. Ilayaraja K., Krishnamurthy R.R., Jayaprakash M., Velmurugan P.M., Muthuraj S.,Characterization of the 26 December 2004 tsunami deposits in Andaman Islands (Bay of Bengal, India),Environmental Earth Sciences,V-66,I-8,PP-2459-2476,Y-2012

27. Ilayaraja K.,Morphometric parameters of micro watershed in Paravanar sub-basin, Cuddalore District,International Journal of Civil Engineering and Technology,V-8,I-8,PP-1444-1449,Y-2017

28. Ilayaraja K., Singh R.K., Rana N., Chauhan R., Sutradhar N.,Site suitability assessment for residential areas in south Chennai region using remote sensing and GIS techniques,International Journal of Civil Engineering and Technology,V-8,I-8,PP-1468-1475,Y-2017

29. Ilayaraja K., Reza W., Kumar V., Paul S., Chowdhary R.,Estimation of land surface temperature of Chennai metropolitan area using Landsat images,International Journal of Civil Engineering and Technology,V-8,I-8,PP-1450-1456,Y-2017

30. Chitra R.,Experimental study on beam using steel fiber and latex,International Journal of Civil Engineering and Technology,V-8,I-8,PP-1395-1403,Y-2017

31. Chitra R.,Analysis of traffic and management at Kovilambakkam intersection,International Journal of Civil Engineering and Technology,V-8,I-8,PP-1433-1443,Y-2017

32. Aswathy M.,Experimental study on light weight foamed concrete, International Journal of Civil Engineering and Technology,V-8,I-8,PP-1404-1412,Y-2017

33. Aswathy M.,Wastewater treatment using constructed wetland with water lettuce (Eichornia Crasipies),International Journal of Civil Engineering and 
Technology,V-8,I-8,PP-1413-1421,Y-2017

34. Kiruthiga K., Anandh K.S., Gunasekaran K, Assessment of influencing factors on improving effectiveness and productivity of construction engineers, 2015, International Journal of Applied Engineering Research, V - 10,I -17,p-13849-13854

\section{AUTHORS PROFILE}

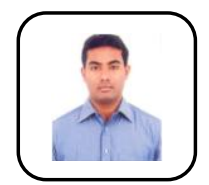

Anish - C ,Assistant Professor, Department of Civil Engineering, Bharath Institute of Higher Education and Research, Chennai, India

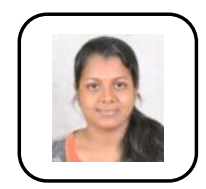

Kiruthiga.K ,Assistant professor, Department of Civil Engineering, Bharath Institute of Higher Education and Research, Chennai, India

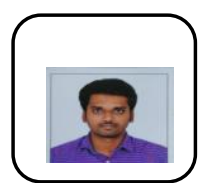

S.Vinoth Assistant professor Department of Civil Engineering, Bharath Institute of Higher Education and Research, Chennai, India 